öz

Bu çalıșmanın amacı, hemşire çalıșma alanlarındaki mekânsal memnuniyeti psikososyal beklentiler üzerinden değerlendirmektir. Bu amaca yönelik, çalışma kapsamında iki ayrı sorgulama yapılacaktır: Hemşirelere ait bireysel parametrelerin çalışma mekânlarındaki psikososyal gereksinimleri üzerinde anlamlı bir etki olușturup olușturmadığ 1 ve psikososyal gereksinimlerin hemşireler tarafından çalışma mekânlarında yeterli görülüp görülmediği sorgulanmıştır.

Sağlık çalışanlarından hemşireleri ele alan bu çalı̧̧mada, hemşirelerin çalışma mekânlarındaki mekânsal memnuniyetlerini etkileyen faktörler; bireysel ve mekânsal olarak iki ayrı grupta değerlendirilmektedir. Bu çalısmada bireyden kaynaklanan veriler; yaş, cinsiyet, belirlenen hastanede çalışma süresi ve çalışanın engel durumu başlıkları altında öznel olarak değerlendirilebilecek ölçütler olarak belirlenmiştir. Mekânsal memnuniyeti etkileyen mekândan kaynaklanan etkenler ise fiziksel ve psikososyal etkenler olarak iki grupta değerlendirilmektedir. Fiziksel etkenler; renk, malzeme, doku, mobilya düzeni, akustik, havalandırma, koku, 1sı vb. iken; psikososyal etkenler, aidiyet, mahremiyet, kontrol etme arzusu, güvenlik, bireysel mesafelere sayg1 (sinır) olarak düşünülmüştür.

Araștırmada dört farklı veri toplama yöntemi kullanılmıştır: Literatür verileri ve araștırmacıların yapmıs oldukları gözlemlerin yanı sıra, yapılan anket ve mülakat çalışmalarından elde edilen veriler çalıșmanın bulgularını olușturmaktadır. Araştırmada elde edilen bulgular; mekânların doğru analiz edilebilmesi amacıyla iki hastane hemşireleri için ayrı ayrı ele alınmıştır. Araştırmanın evrenini; İzmir ili çevresinde yer alan Çeşme Devlet Hastanesi $(C \zeta D H)$ ve Urla Devlet Hastanesinde (UDH) çalışan hemşireler oluşturmaktadır.

Hemşirelerin çalışma alanlarında psikososyal gereksinimleri karşılamaya yönelik mekânsal verilerin yeterliliği incelendiğinde; doğal ve yapay ıșık, gürültü ve koku kontrolü, güvenlik, aidiyet, sınır ve mahremiyet konularında önemli eksiklikler olduğu görülmüștür. Bu olumsuzlukların giderilmesi için sağlık çalışanlarına yönelik iç mekânlarda detaylı çalışmalar yapılmasının öncelikle insan hakları ve çalıșan haklarının korunması, sonrasında hastaya karşı olan hoşgörü ve iyi iş gücü anlamında iş performanslarının artması, strese, güvenlik ihlaline ve yorgunluğa bağlı iş kazalarının azalması ve dolayısıyla sağlık hizmetlerinin veriminin artması için son derece önem taşıdığı anlaşılmaktadır.

Anahtar Kelimeler: Sağlık iç mekânları, hemșire çalıșma alanları, mekânsal memnuniyet, psikososyal etkenler.

\section{Hemşire Çalışma Alanlarının Mekânsal Memnuniyet Açısından Değerlendirilmesi'}

\author{
(D) Çĭgdem Çetin \\ Yaşar Üniversitesi Mimarlık Fakültesi, İç Mimarlık ve Çevre Tasarımı Bölümü, İzmir, Türkiye \\ (1) Gülnur Ballice \\ Yaşar Üniversitesi Mimarlık Fakültesi, Iç Mimarlık ve Çevre Tasarımı Bölümü, İzmir, Türkiye \\ (D) Zeynep Tuna Ultav \\ Yaşar Üniversitesi Mimarlık Fakültesi, İç Mimarlıkve Çevre Tasarımı Bölümü, İzmir, Türkiye \\ Başvuru tarihi/Received: 15.04.2021, Kabul tarihi/Final Acceptance: 08.07.2021
}

Extended Abstract

Physical factors of the space consist of more subjective and measurable elements. Visual, dimensional, tactile, thermal, olfactory and auditory data that appeal to all sensory pathways are among the constituents of physical existence of an individual. The dimensions, form, vertical and horizontal elements of the space, its color, texture and material features, and the perception it creates with stimuli such as sound and smell are the spatial dimension of physical satisfaction (Baylzitloğlu, 2009; Saegert, 2004). The aim of this study is to evaluate the spatial satisfaction in nurse working areas through psychosocial expectations. For this purpose, two separate inquiries were made within the scope of the study: It was questioned whether the individual parameters of nurses had a significant effect on the psychosocial needs in the workplaces and whether the psychosocial needs were seen as sufficient by the nurses in the workplaces.

It is noteworthy that there are very few studies evaluating the satisfaction of nurses, whose spatial satisfaction is directly or indirectly affected. Some of the reasons for this can be listed as follows: Failure to create sufficient training and awareness in this regard, not allocating the budget to meet the spatial needs of nurses, patient-priority perspective, insufficient space allocated for nurses in health interiors, insufficient standards for these spaces in the regulations, and interior design decisions to be regarded as secondary importance.

For all these reasons mentioned above, nurse working places do not have spatial data to meet the psychosocial expectations of nurses and to ensure their spatial satisfaction in this context. Spatial satisfaction, in general terms, is that an individual feels good in the place he/she is in, with the data originating from the place. In terms of healthcare spaces and healthcare professionals, it provides spatial satisfaction by reducing the factors that affect healthcare professionals negatively and increasing the positive spatial factors with indoor design parameters and supporting their satisfaction in the space (Tanriöver, 2016).

In this study, which deals with nurses from healthcare professionals, the factors affecting the spatial satisfaction of nurses in their workplaces, it is evaluated in two separate groups, individually and spatially. In addition to the person's physiological characteristics, gender and age, depending on the social class and the education he/she has acquired, the culture, habits and past experiences, and the temporal characteristics such as his/her feelings in the place at that moment, purpose, wishes and point of view constitute individual data (Tavakkoli, 2014). Data originating from the individual in this study; age, gender, duration of working in the specified hospital and disability of the employee were determined as criteria that can be evaluated subjectively. Space-related factors affecting spatial satisfaction are evaluated in two groups as physical and psychosocial factors. Physical factors; color, material, texture, furniture layout, acoustics, ventilation, odor, heat, etc. while psychosocial factors are considered as belonging, privacy, desire to control, security, respect for individual distances (border).

Four different data collection methods were used in the study: In addition to the literature data and the observations made by the researchers, the data obtained from the survey and interview studies constitute the findings of the study. The findings of the research were considered separately for the two hospital nurses in order to analyze the interior spaces correctly. The universe of the research includes nurses working at Çeşme State Hospital (ÇDH) and Urla State Hospital (UDH), which are located around İmir province.

When examining the adequacy of spatial data to meet the psychosocial needs of nurses in their working areas, it has been observed that there are significant deficiencies in natural and artificial light, noise and odor control, security, belonging, border and privacy. It is understood that in order to eliminate these inadequate circumstances, carrying out detailed studies for healthcare professionals indoors, first of all, to protect human rights and employee rights, then to increase work performance in terms of tolerance and a good workforce to the patient, to decrease occupational accidents due to stress, violation of safety and fatigue and thus to increase the efficiency of health services are extremely important.

Keywords: Healthcare interiors, nurse workplaces, spatial satisfaction, psychosocial factors.

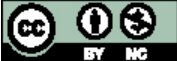




\section{Giriş}

Mekânsal memnuniyet, özellikle çalışma alanlarında kişilerin iyi olma durumlarını etkileyen önemli bir kavramdır. Bir kişiden başlayıp tüm çalışma gruplarına yayılan bu deneyim, bireylerin iş tatminlerini de önemli ölçüde etkilemektedir. Bu konuda çalışmaları olan Locke'a $(1976,105)$ paralel olarak, De Nobile $(2003,3)$ de iş tatminini mekâna karşı olan pozitif değerlendirmeyle paralel olarak görmektedir. Miner $(1992,10)$ ise, yapılan işin kalitesinin iş tatminiyle birlikte gelişeceğini savunmaktadır. Dolayısıyla mekânsal memnuniyetin olmadığ 1 çalışma ortamlarında iş tatmininden ve kalitesinden bahsetmenin mümkün görünmediği anlaşılmaktadır. Mekânsal memnuniyetin sağlanamadığı çalışma ortamlarında, çalışanların stres ve yorgunluk seviyelerinin daha yüksek olması nedeniyle iş performansı ve kalitesi de olumsuz etkilenmektedir (Salama ve Courtney, 2013). ${ }^{2}$ Özellikle sağlık yapılarında mekânsal memnuniyet çok daha büyük öneme sahiptir. Malloch ve O'Grady'e (2006, 243) göre yapılı çevre ile uygulama arasındaki uyumun iyiliği, sağlık bakım sisteminin başarısı için kritik öneme sahiptir. Benzer şekilde araştırmalar, personelin iyi olma durumunun, üretkenliğinin ve memnuniyetinin bir hastanenin fiziksel ortamıyla, özellikle de bir binanın yaşam döngüsünün erken tasarım aşamalarında belirlenen hususlarla bağlantılı olduğunu göstermektedir (Mourshed ve Zhao, 2012). Başka bir çalışma ise, çalışma ortamının sağlık personelinin verimliliği, üretkenliği, memnuniyeti ve hasta sağlık çıktıları üzerindeki etkisine ilişkin çok sayıda kanıt sunmakta, mevcut durumda iyi tasarlanmamış hastane çalışma ortamlarının yaygın olduğunu ve bu durumun olumsuz sağlık sonuçlarına ve düşük bakım kalitesine neden olduğunu savunmaktadır (Aiken vd., 2011).

Hasta ve sağlık çalışanlarının verimleri konusunda yapılan literatür çalışmalarının temelde üç grupta ele alınabileceği kanıta dayalı çalışmalarla ortaya çıkarılmıştır; çalışanların stres ve yorgunluğunu azaltmak ve dolayısıyla iş performansını arttırmak, hasta güvenliğini arttırmak ve tüm sağlık kalitesini arttırmak (Ulrich vd., 2004). Sağlık mekânları kullanıcıları ile ilgili literatür ele alındığında; , hastalar konusunda daha çok çalışma olduğu ortaya çıkmış, öte yandan doktor ve hemşireler ile ilgili araştırmaları içeren az sayıda çalıșmaya ulaşılmıștır (Nejati vd., 2016). Bunun yanı sıra, sağlık çalışanlarının stres ve yorgunluğunu azaltmak üzerine yapılan araştırmalar sağlık mekânları çalışmaları kapsamında ele alınması gereken önemli bir konudur (Ulrich vd., 2004). Özellikle mesai ve nöbet saatleri oldukça yoğun olan hemşireler için bu durum daha da önemli hale gelmektedir. Son y1llarda hemşirelerin iş yükü arttıkça, mental yükleri ve çoklu görevleri giderek artmaktadır (Potter vd., 2005). Mevcut tasarım çözümleri bu değişime ayak uydurmalı ve sağlık kuruluşlarının odaklandığı verimlilik hedeflerine doğru ilerlemelidir (Zadeh $v d$., 2012). Hemşireler, sistemin klinik olmayan verimsiz yönleri nedeniyle aşırı iş yükü altında kaldığında, hasta bakımının kalitesi de paralel olarak etkilenmektedir (RWJF ve IHI, 2006). Hemşirelerin memnuniyeti için, çalışma alanlarının daha az hataya yol açacak şekilde düzenlenmesi kritik öneme sahiptir. Zorlu iş yüküne rağmen, hemşireler çoklu sistem verimsizliklerinin varlığında hasta güvenliğini sağlamalıdır (Ebright, Patterson, Chalko ve Render, 2003). Her ne kadar tıbbi hataların \% 90'a kadarı sistem verimsizliği ve başarısızlığından kaynaklansa da (Reason, 1997'den aktaran RWJF ve IHI, 2006), hasta bir hatadan etkilendiğinde, bakıcı duygusal olarak kendini sorumlu hissetmekte, bu da sağlık çalışanlarının tükenmişliğine ve memnuniyetsizlik hissi yaşamasına sebep olmaktadır. Rutinlerde, sistemlerde veya mekânlarda bulunan birçok hata hastalara zarar vermekte ve bu durum sağlık çalışanlarında artan sıkıntı ve tükenmişliğe, dolaylı olarak kendilerini suçlu hissederek işten ayrılmalara neden olmaktadır (Wu, 2000, s. 726). Uzun süreli vakit geçirilen bu mekânların hemşireleri olumlu yönde etkilemesi, hem fiziksel hem de psikososyal sağlıkları için önem taşımaktadır. Aksi durumda çalışma mekânlarındaki memnuniyetsizlik, hemşirelerde strese yol açmakta, dolayısıyla iş performanslarını düşürmekte ve hata paylarını 
arttırmaktadır. Ayrıca, hasta ile tedavi sürecinde en yakın temasta olan sağlık çalıșanı olan hemşirelerin, hastanın iyi olma durumunu sağlamak için görevlendirilmiş bireyler oldukları göz önüne alındığında, onların memnuniyetinin dolaylı olarak hastanın iyi olma durumunu da etkilediği düşünülmektedir. Dünya Sağlık Örgütü tarafindan yayınlanan bir araştırmada (World Health Statistics Report) dünyada hemşire sayılarının artan bir oranla azaldığı rapor edilmiş ve hastanelerde çalışan hemşirelerin yaş ortalamasının gitgide arttığı izlenmiştir. $\mathrm{Bu}$ değişimin belirleyicilerinin çok yönlü olduğu ve çalışmanın bağlamına ve araştırmacının bakış açısına göre farklılaştığı belirlenmiştir (Hayes vd., 2006). Bununla birlikte, liderlik ve yönetim yaklaşımlarındaki farklılıklara ek olarak (Cummings $v d$., 2010) çalışma ortamı tasarımının personel değişim hızını etkilediği yaygın olarak görülmüştür (Hayes vd., 2006; Jones, 2005). Dalke vd. (2006) çok sayıda personelin, iyi tasarlanmış bir çalışma ortamının, personelin işe alınmasına ve tutulmasına yardımcı olmasının yanı sıra moralinin yükselmesine yardımcı olabileceğini belirtmektedir. Amerika'da yapılan araştırmalar sonucunda 43 olan yaş ortalamasının 2010 yılında 50 olacağ ${ }_{1}$ ve her yıl $\% 20$ oranında çalışan hemşire sayısının azalacağı öngörülmüştür (Haddad vd., 2020). 2020'de Amerika Hemşirelik Kolejleri Derneği'nin (AACN-The American Association of Colleges of Nursing) yaptığ 1 bir çalışmada 1996 yılında hastanelerde kaydedilen 1609 ölüm ve yaralanma vakasının \%24'ünün hemşire bilgi zayıflığından kaynaklandığı açıklanmıştır (The American Association of Colleges of Nursing, t.y.). Yapılan araştırmalar sonucunda, hemşirelerin bilgi azlığı ya da eksik sayıda çalışmak durumunda kalmaları nedeniyle, işlerinin aksadığı, hata oranlarının arttığ hastaların da bu durumdan etkilenerek sağlıklarının riske girdiği anlaşılmaktadır (Ulrich vd., 2004).

Doğrudan ve dolaylı olarak etki alanı oldukça fazla olan mekânsal memnuniyet konusunda hemşirelerin çalışma alanlarını değerlendiren oldukça az sayıda çalışma olması dikkat çekicidir. Bunun nedenleri arasında; bu konuda yeterli eğitim ve farkındalığın yaratılamaması, hemşirelerin mekânsal gereksinimlerini sağlayacak bütçenin ayrılamaması, hasta öncelikli bakış açısı, sağlık iç mekânlarında hemşireler için ayrılan mekân boyutlarının yetersizliği, yönetmeliklerde bu mekânlar için yeterli standartların oluşturulmaması ve iç mekân tasarım kararlarının mimari kararlara göre ikincil önemde görülmesi sayılabilir.

Yukarıda bahsedilen tüm bu nedenlerden dolayı hemşire çalışma mekânları, hemşirelerin psikososyal beklentilerini karşılayacak ve bu bağlamda mekânsal memnuniyetlerini sağlayacak verilere sahip değildir. Mekânsal memnuniyet, genel tanımıyla, bireyin bulunduğu mekânda, mekândan kaynaklı verilerle kendini iyi hissetmesidir. Sağlıkla ilgili mekânlar ve çalışanlar özelinde ise, iç mekân tasarım parametreleriyle çalışanları olumsuz yönde etkileyen faktörleri azaltıp, olumlu mekânsal faktörleri arttırarak, onların mekândaki tatminlerini desteklemek mekânsal memnuniyeti sağlamaktadır (Tanrıöver, 2016).

Sağlık çalışanı olan hemşireleri ele alan bu çalışmada, hemşirelerin çalışma mekânlarındaki mekânsal memnuniyetlerini etkileyen faktörler; bireysel ve mekânsal olarak iki ayrı grupta değerlendirilmektedir. Kişinin fizyolojik özellikleri, cinsiyeti, yaşı, içinde bulunduğu sosyal sınıfa ve aldığı eğitime bağlı olarak sonradan edindiğ kültürü, alışkanlıkları, geçmiş deneyimleri,mekânda o anda hissettikleri, amac1, istekleri ve görüş açısı gibi geçici özellikleri

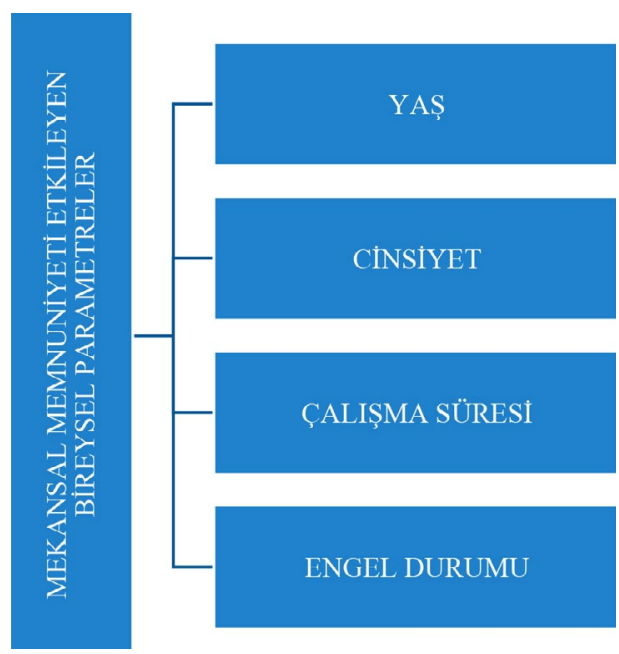

Sekil: I

Mekânsal memnuniyeti etkileyen bireysel parametreler. 


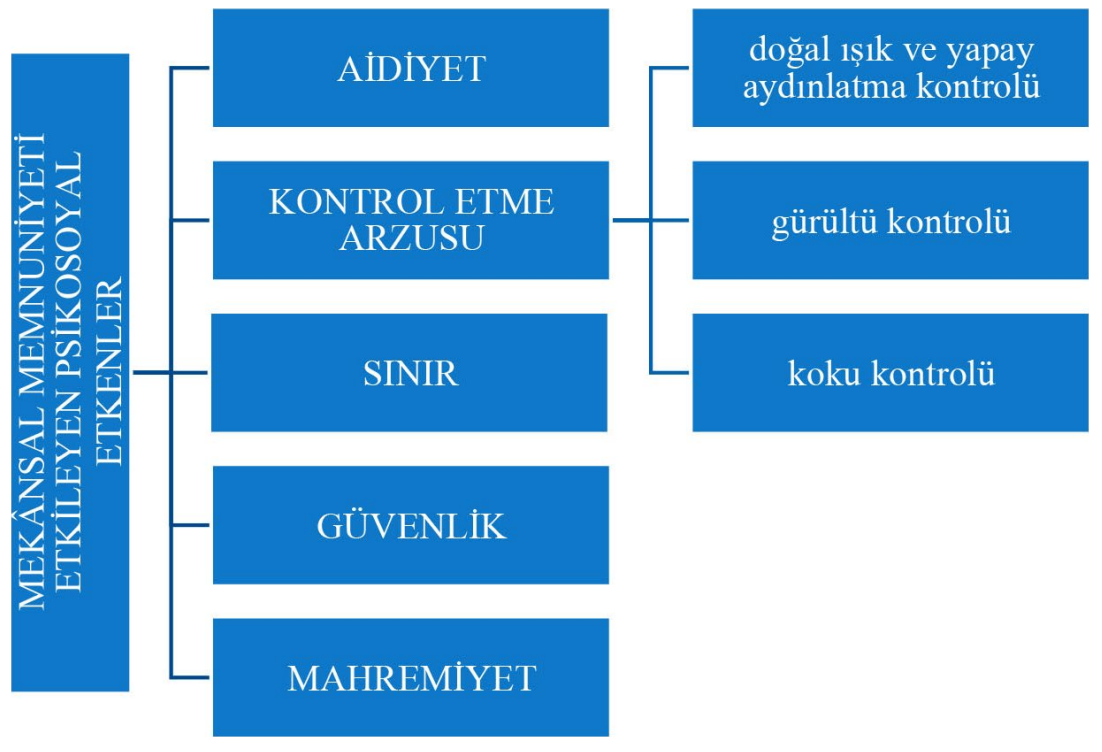

Şekil: 2

Mekânsal memnuniyeti etkileyen psikososyal etkenler. bireysel verileri oluşturmaktadır (Tavakkoli, 2014). Bu çalışmada bireyden kaynaklanan veriler; yaş, cinsiyet, belirlenen hastanede çalışma süresi ve engel durumu başlıkları altında öznel olarak değerlendirilebilecek ölçütler olarak belirlenmiştir (Şekil 1).

Çalışmada mekânsal memnuniyeti etkileyen mekândan kaynaklanan etkenler ise fiziksel ve psikososyal etkenler olarak iki grupta değerlendirilmektedir. Fiziksel etkenler; renk, malzeme, doku, mobilya düzeni, akustik, havalandırma, koku, 1sı vb. iken; psikososyal etkenler; aidiyet, mahremiyet, kontrol etme arzusu, güvenlik, bireysel mesafelere saygı (sinır) olarak düşünülmüştür (Şekil 2).

Mekânın fiziksel etkenleri daha öznel ve ölçülebilir öğelerinden oluşmaktadır. Bireyin tüm duyum yollarına hitap eden görsel, boyutsal, dokunsal, 1sısal, kokusal ve işitsel veriler fiziksel varlığının yapıtaşlarıdır. Mekânın boyutları, formu, düşey ve yatay elemanları, sahip olduğu renk, doku ve malzeme özellikleri ile ses, koku gibi uyarıcılar ile oluşturduğu algı, fiziksel memnuniyetin mekânsal boyutudur (Bayızıtlıŏglu, 2009; Saegert, 2004). Bu çalışmanın amacı, hemşire çalışma alanlarındaki mekânsal memnuniyeti psikososyal beklentiler üzerinden değerlendirmektir. Bu amaca yönelik olarak, çalışma kapsamında iki ayrı sorgulama yapılmıştır; hemşirelere ait bireysel parametrelerin çalışma mekânla- rındaki psikososyal gereksinimleri üzerinde anlamlı bir etki oluşturup oluşturmadığ 1 ve psikososyal gereksinimlerin hemşireler tarafından çalıșma mekânlarında yeterli görülüp görülmediği sorgulanmıştır.

\section{Mekânsal Memnuniyette Psikososyal Etkenler}

Mekânsal memnuniyeti etkileyen psikososyal etkenler, kullanıcının psikolojik ve sosyal beklentilerinin sonucu olarak ortaya çıkmaktadır. Bu bağlamda, bu kısımda daha çok bireyin beklentileri üzerinde yoğunlaşılmıştır. Psikolojik beklentilerin değerlendirilmesi ancak sosyolojik beklentilerle birlikte bir bütün olarak ele alınması ile mümkün olmaktadır. Özellikle, gün içinde çok sayıda kullanıcı tarafından kullanılan hemşire çalışma alanlarında sosyolojik ilişkiler psikolojik beklentileri oldukça fazla etkilemektedir. Kullanıcının aidiyet, kontrol edebilme, mahremiyet, güvenlik, bireysel mesafelere duyarlılık (sinır) yönündeki beklentileri psikososyal etkenler üzerindeki beklentileri oluşturmaktadır.

Sağlık iç mekânlarında psikososyal beklentilerin karşılanması, özellikle uzun çalışma saatleri ve yoğun çalışma temposu olan hemşireler için önem arz etmektedir.

Aidiyet kavramı, kendine ait olma hissi ve kendini o mekâna ait hissetme fikri olarak düşünülebilir. Kişinin bunu hissedebilmesi, mekânda kendine ait izleri ve nesneleri kullanabilmesiyle mümkündür. Aidiyetin duygusal ve fonksiyonel boyutu vardır. Kullanıcının kendi için anlamı ve değeri olan mekânlarla kurduğu duygusal bağın yanı sıra, belirli bir aktiviteyi gerçekleştirmek için gerek duyduğu fonksiyonel bir bağ da bulunmaktadır (Relph, 1976; Tuan, 1977). Aidiyetin çalışma alanlarındaki önemi üzerine Wells (2000), aidiyet hissinin çalışma alanlarında fizyolojik ve psikolojik sağlığı etkilediğini öne sürmektedir. Mekânı kişiselleştirme yoluyla aidiyetin arttığını savunan Donald (1994), insanların mekânları kişiselleştirme arzularının olduğunu belirtmektedir. Cinsiyet farklılıkların aidiyet kurma isteği üzerine etkisi olduğunu savunan Wells (2000), kadınların çalışma alanlarında kendilerine ait daha çok nesne (kişisel ilişkilerine ait sembolleri, arkadaş ve evcil hayvan fotoğraflart, 
biblo $v$ b.) bulundurduklarını belirtmiştir. Yine aynı çalışmada mekânsal aidiyetini sağlayamayan çalışanların, mekânsal memnuniyetinin düştüğü, dolayısıyla iş memnuniyeti ve psikolojik refah konusunda eksiklik yaşadıkları ifade edilmiştir (Wells, 2000).

Kontrol etme arzusu, kişinin yapacağ 1 şeyleri ya da kendine yapılabilecekleri belirleyebilme yetisi olarak tanımlanabilir (Gatchel vd., 1989). Yapılan bir çalışmada görülmüştür ki; kontrol etme hissinin fazla olduğu kişilerde stresle başa çıkma seviyesi, kontrolü yitirdiğini düşünen kişilere göre daha fazladır (Evans ve Cohen, 1987; Ulrich, 1999). Mahremiyetin kontrol edildiği, aydınlatmanın ayarlanarak kontrol edilebildiği ve engeli olanların bahçe ya da genel olarak açık alanlara ulaşabildiği mekânlar kontrol etme hissinin desteklendiği mekânlar olarak değerlendirilmektedir (Ulrich, 2021). Benzer olarak, çalışana hastanenin stresli çalışma ortamından geçici olarak kaçabileceği hissini veren ayarlanabilir çalışma istasyonları ve konforlu dinlenme alanları; kontrolün desteklendiği, dolayısıyla sağlık çalışanının stresinin azaldığı çalışma alanları olarak görülmektedir (O’Neill ve Evans, 2000). Gürültünün kontrolü, sağlık çalışanları için önemli bir stres belirleyicisi olarak görülmektedir. Yapılan çalışmalar, çalışanların yüksek ses seviyelerini stres verici olarak değerlendirdiğini kanıtlamaktadır (Bayo vd., 1995; Norbeck, 1985; Ulrich vd., 2004). Ayrica gürültü sebebiyle oluşan stres, hemşirelerde duygusal yıpranma ve işten ayrılmaya sebep olmaktadir (Topf ve Dillon, 1988; Ulrich vd., 2004). Blomkvist vd. (2005) tarafindan koroner yoğun bakım biriminde çalışan hemşireler ile yapılan çalışmada, düşük gürültü seviyelerinin; algılanan iş talebini azalttığı, iş yerinde algılanan sosyal desteği arttırdığı, hastalar için iş kalitesini arttırdığı, daha iyi konuşma becerisi sağladığ1 görülmüştür. Çalışanların stres seviyelerini etkileyen bir diğer etken, koku kontrolüdür. Koku, beynin duygusal merkezi olan limbik sistemle güçlü bir bağ kurduğu için, görme ve duyma duyularına göre daha akılda kalıcıdır. Dolayısıyla hemşirelerin her gün kullandıkları çalışma alanlarında onları karşılayan ve negatif yönde etkileyebilecek herhangi bir koku, onların çalışma etkinliklerini ile iş tatminlerini azaltarak iş bırakma olasılıklarını arttıracaktır. Medikal kaynaklı doğal olmayan kötü kokular endişeyi, stresi ve korkuyu arttırırken, hoş aromalar kan basınıcını azaltmakta solunumu yavaşlatmakta ve düşük acı algısı sağlamaktadır (Applebaum, 2008).

Sınır kavramı; sadece ayırıcı niteliği olaniçi dolu somut bir engel olarak değerlendirilmemeli, aynı zamanda ayırdığı öğeler arasında ilişki kuran bir özelliğinin de olması beklenmelidir. Sınır kavramı, kişisel alan kavramıyla birlikte kullanılır ve değerlendirilir (Berberoğlu 2010, 69). Sınırlar, özellikle kişisel alanın korunmasının önemli olduğu sağlık iç mekânlarında kişilerin kendilerini güvende hissettikleri alanlarını çizmeleri ve korumaları için gerekli fonksiyonel elemanlar haline dönüşmektedir. Mimari ve iç mimari çözümlerle bu sınırların tanımlanması hastalar için olduğu kadar, sağlık çalışanları için de psikolojik ve fiziksel bir gerekliliktir. İç mekânda kullanılan mobilyaların yerleşimi ve türü, sosyal iletişimde bir sınır görevi görebilir. Bu sınır, uygun kullanıldığı takdirde göz kontağı ve uygun diyaloğa izin verirken, yanlış kullanımında istenilenden daha yakın ya da uzak mesafe oluşturarak sosyalleşmeyi olumsuz bir biçimde de etkileyebilir (Evans ve McCoy, 1998).

Kişinin kendini güvende hissetmesi, korkusuzca yaşaması olarak tanımlanabilecek güvenlik kavramı, hemşirelerin çalışma ortamı için değerlendirildiğinde; olası iş kazalarından, hasta veya yakını tarafindan doğabilecek herhangi bir şiddet vakasından ve/ya herhangi zararlı bir maddenin solunum yoluyla alınmasından korunma gibi anlamlar taşımaktadır.

Mekânsal memnuniyeti etkileyen psikososyal etkenlerden bir diğeri olan mahremiyet; kişinin görsel, işitsel ve toplumsal boyutta diğer insanlarla olan ilişkisine karar verme koşulu olarak tanımlanabilir. Görsel mahremiyet; çeşitli mobilyaların, bölücülerin ya da duvarların kullanımıyla sağlanır. Bir mekândaki akustik mahremiyet; tavanlar, ayırıcılar, mobilyalar, ekipmanlar ve zemin gibi birçok elemanın birbiriyle olan ilişkisi kullanilarak ve bu elemanlarda etkili bir akustik uygulama ile sağlanabilmektedir 
(Levin ve Groner, 1992). Mahremiyet gereksinimi, mekânın fonksiyonuna göre farklı derecelerde sağlanmalıdır. Sağlık iç mekânları söz konusu olduğunda kısa zaman aralığında zorunlu bir mahremiyet paylaşımı ortaya çıkmaktadır (Berberoğlu 2010, 70). Hemşire çalışma alanlarında, hemşirelerin hasta ve yakınları ile ve diğer personel ile ilişkilerinde mahremiyet gereksinimleri birbirinden farklılık göstermektedir. Bu noktada önemli olan kişilerin gerginliğini arttırmayacak şekilde mahremiyet gereksinimlerini göz önüne almaktır. Bu alanların öncelikle yakınında bulunan alanların doğru planlanması, alan içi mobilya kullanımları, düşey ve yatay mimari elemanların konumu ve özellikleri (akustik malzeme ve konstrüksiyon) hem görsel hem işitsel mahremiyet için önem kazanmaktadır.

\section{Yöntem}

Araştırmada dört farklı veri toplama yöntemi kullanılmıştır; literatür verileri ve araştırmacıların yapmış oldukları gözlemlerin yanı sıra, yapılan anket ve mülakat çalışmalarından elde edilen veriler çalışmanın bulgularını oluşturmaktadır.

Araştırmada elde edilen bulgular; mekânların doğru analiz edilebilmesi amacıyla iki hastane hemşireleri için ayrı ayrı değerlendirmeye alınmıştır. Araştırmanın evrenini; İzmir ili çevresinde yer alan Çeşme Devlet Hastanesi $(C ̧ D H)$ ve Urla Devlet Hastanesinde (UDH) çalışan hemşireler oluşturmaktadır. Çeşme'de 42, Urla'da 120 hemşire çalışmakta olup belirlenen sayıda hemşire basit, rastgele örnekleme yöntemi ile çalışmaya dâhil edilmiştir.

Anket çalışmasında kullanıcıların psikososyal gereksinimlerini değerlendirmeye yönelik beş adet soru yer almaktadır. Bu sorular beşli Likert ölçeği kullanılarak hazırlanmıștır. ${ }^{3}$ Veriler, bilgisayar ortamında SPSS 16.0 programında değerlendirilmiştir. Anket verilerinin değerlendirilmesinde istatistiksel anlamlılık düzeyi için $\mathrm{p}<0,005$ kabul edilmiştir.

Anketin uzunluğu ve alınan cevapların sinırlılığı nedeniyle anket soruları kontrol, güvenlik konuları (aydınlatma kontrolü, gürültü kontrolü ve güvenlik için bireysel parametreler) ile sınırlandırılmıştır. Mülakat sorularında ise bu konulara aidiyet, mahremiyet ve sinır konuları da eklenerek derinlemesine görüşme yöntemi ile bilgi almak hedeflenmiştir.

Çalışmanın veri paketini oluşturan bir diğer yöntem ise mülakattır. Mülakat çalışması, birebir derinlemesine görüşme yöntemiyle her iki hastaneden ikişer hemşire ile gerçekleştirilmiştir. Mülakat soruları, anket sorularından elde edilen bilgilerin desteklenmenin yanı sıra daha kapsamlı bilgi alabilmek için düzenlenmiştir. Psikososyal beklentilere ilişkin sorular anket ve mülakat soruları ile katılımcılara yönlendirilmiştir.

\section{Bulgular}

\subsection{Anket Verileri}

Çalışmanın belirlediği bireysel etmenler; giriş bölümünde de belirtildiği üzere, cinsiyet, yaş, engel durumu ve çalışılan süredir. Bu bağlamda, ÇDH'de çalışan hemşirelerin tamamının kadın olduğu görülmektedir. Yaş grupları incelendiğinde; anket sorularında belirtilen gruplara göre; katılımcılarin \%43,5'inin 31-40, \%34,8'inin 41-50, $\% 10,9$ 'unun 21-25 ve \%10,9'unun 26-30 yaş aralığında olduğu görülmektedir. Katılımciların engel durumları incelendiğinde; \%6,3'ünün işitme engeli olduğu görülmüştür. Katılımcıların çalıştıkları süreler incelendiğinde; \%12,5'inin 6-11 ay, \%31,3'ünün 1-4 y1l, \%25'inin 5-10 y1l ve \%31,3'ünün 10 yıldan fazladır ÇDH'de çalıştı̆̆ı görülmektedir.

UDH'de çalışan hemşirelerin; \%6,7'si 21-25, \%6,7'si 26-30, \%46,7'si 31-40 ve \%40’1 41-50 yaş aralığındadır. Katlımc1ların engel durumları incelendiğinde; \%3,3'ünün görme engeli olduğu görülmektedir. Katılımcıların çalıştıkları süreler incelendiğinde; \%3,3'ünün 1 aydan daha az, \%3,3'ünün 1- 5 ay, \%13,3'ünün 6-11 ay, \%40'1nın 1-4 yıl, \%20'sinin 5-10 yıl ve $\% 20$ 'sinin 10 yıldan fazladır UDH'de çalıştığı görülmektedir.

Araştırma katılımcılarının psikososyal beklentilerinin mekânsal olarak ne derece karşılandığını değerlendirmek üzere sorulan sorular ÇDH ve UDH olarak iki ayrı hastane özelinde değerlendirmeye alınmıştır. 


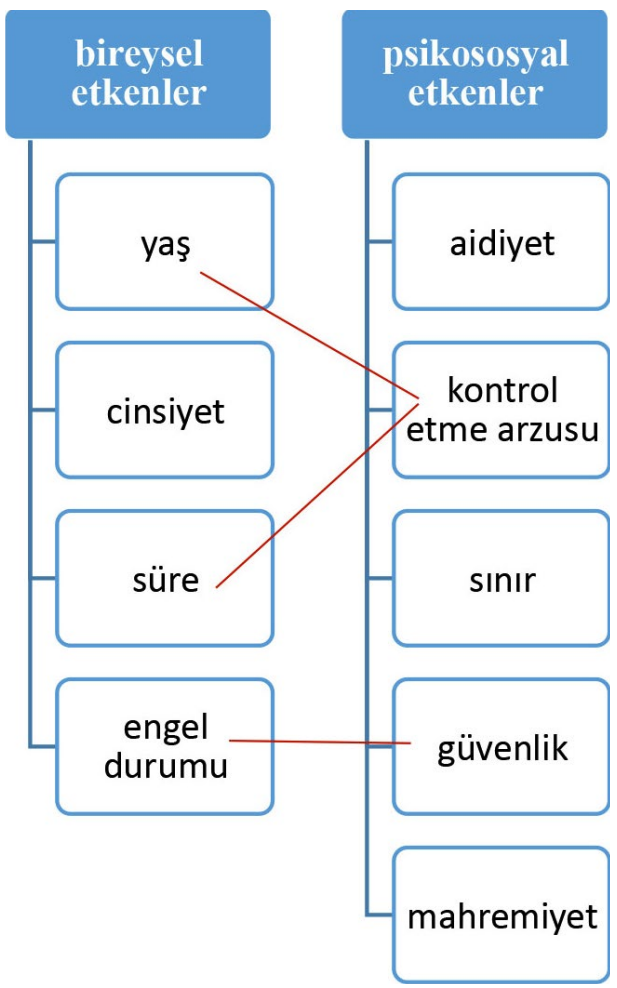

Araştırma katılımcılarının psikososyal beklentilerinden biri olan kontrolün, çalışma mekânlarında onlar için ne derece yeterli olduğunu görmek üzere anket kapsamında katılımcılara iki ayrı soru yönlendirilmiştir.

Sorular doğrultusunda ÇDH'de, katılım-
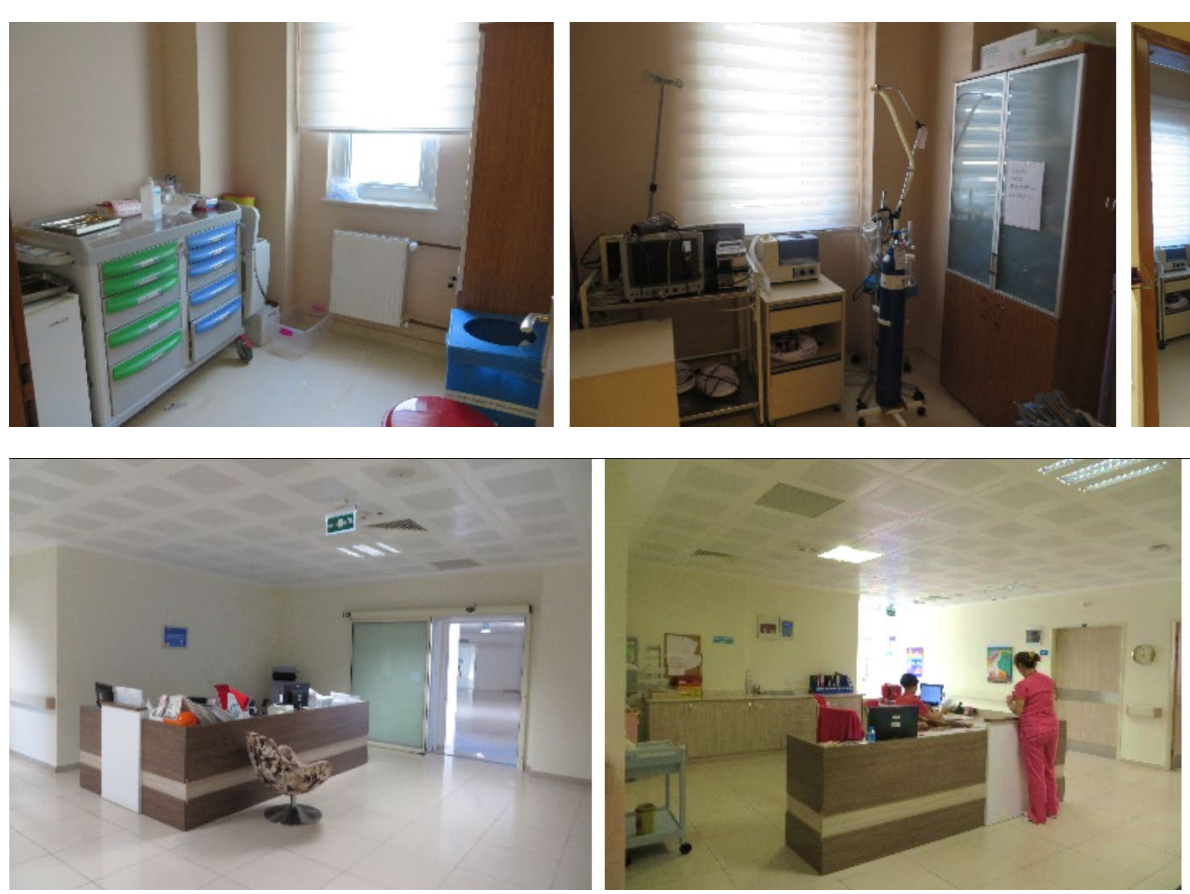

cılardan \%46,2'si doğal ışı kontrolünün yeterince yapılabildiği konusuna "kesinlikle katılıyorum" cevabını verirken, $\% 30,8$ ' $i$ "katılıyorum" ölçeğinde cevap vermiştir. \%15,4 katılımcı ise "katılmıyorum" cevabıyla doğal ışığın kontrolünü yetersiz bulduğunu ifade etmiştir.

UDH'de ise katılımcilardan \%36,7'si doğal 1şık kontrolünün yeterince yapılabildiği konusuna "katılıyorum" cevabını verirken, \%13,3'ü "kararsızım" cevabını vermiştir. \%26,7 katılımc1 "katılmiyorum" cevabiyla doğal ışığın kontrolünü yetersiz bulduğunu ifade ederken, \%23,3 katılımc1 ise "kesinlikle katılmıyorum" cevabiyla olumsuz bir ifade belirtmiştir (Tablo 1). Yapay aydınlatma kontrolüne dair ise, ÇDH'de katılımc1ların \% 46,2'si yapay aydınlatmanın kontrolünün yeterince yapılabildiği konusuna "kesinlikle katılıyorum" cevabını verirken, \%30,8'i "katılıyorum" cevabı vermiştir. \%15,4 kat1lımc ise "katılmıorum" cevabıyla yapay aydınlatmanın kontrolünü yetersiz bulduğunu ifade etmiştir. UDH'de ise katılımcıların \% 46,7'si yapay aydınlatmanın kontrolünün yeterince yapılabildiği konusuna "katılıyorum" cevabını verirken, \%20'si "kararsızım" ve \%2'si ise "katılmıyorum" cevabını vermiştir (Tablo 2) (Şekil $4,5)$.
Şekil: 3

Anket verilerinin çapraz değerlendirilmesi.
Şekil: 4

Çeşme Devlet Hastanesi, hemşire f̧alışma alanları doğal/yapay aydınlatma kontrolü. şekil: 5

Urla Devlet Hastanesi, hemşire çalışma alanları doğal/yapay aydınlatma kontrolü.
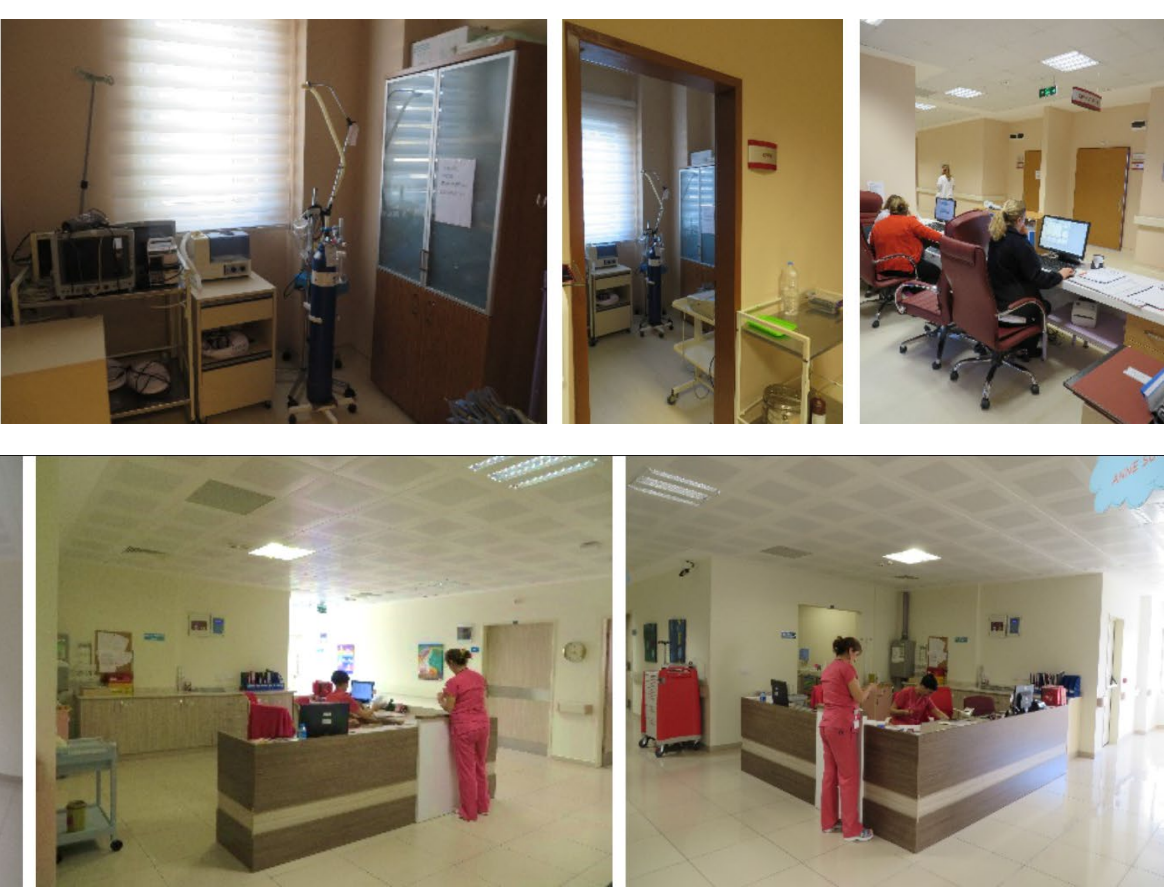
Tablo: 1

Hemşire Çalışma alanlarında doğal ışık kontrolü konusunda anket sorusuna verilen cevaplar.

Tablo: 2

Hemşire çalışma alanlarında yapay aydınlatma kontrolü konusunda anket sorusuna verilen cevaplar.

Tablo: 3

Hemşire çalışma alanlarında gürültü kontrolü konusunda anket sorusuna verilen cevaplar.
Çalışma mekânlarındaki gürültü kontrolü konusunda ÇDH katılımcılarından \%30,8’i "kesinlikle katılıyorum" ve yine aynı oranda katılıyorum cevabını verirken, \%23'ü "kararsız" olduklarını belirtmiștir. \% 15,4 katılımc ise "katılmıyorum" cevabını vermiștir. UDH katılımcılarından ise \%20'si "kesinlikle katıliyorum" ve \%46,7'si "katılıyorum”, \%6,7'si “kararsızım”, \%20'si "katılmiyorum" ve \%6,7'si ise "kesinlikle katılmıyorum" cevabını vermiştir (Tablo 3). Çalışmanın belirlediği bir diğer psikososyal gereksinim olan güvenlik konusu anket içerisinde, iş kazaları çerçevesinde değerlendirilmiş; kablo, priz, zemin malzemesi ile mobilyaların ergonomi için uygunluğu gibi değişkenler sorgulanmıştır. $\mathrm{Bu}$ doğrultuda kullanıcılara çoktan seçmeli sorular yönlendirilmiştir. ÇDH'de katılımc1lardan \%84,6'sı kabloları ve mobilyaları, \%100'ü zemin malzemesini, \%92,3’ü mekânın boyutlarını ve tıbbi elemanları olumsuz olarak görürken; \%100'ü prizleri risk olarak gördüğünü belirtmiştir. UDH'de ise katılımc1lardan \%80'i kabloları, \%70’i mobilyaları, \%60’1 zemin malzemesini, \%83,3'ü mekânın boyutlarını, \%60’1 tıbbi elemanları ve \%60’1 prizleri risk olarak gördüğünü belirtmiştir.

Çalışmanın bireysel etkenler olarak belirlediği cinsiyet, yaş, engel durumu, çalışılan bölüm ve çalışılan süre parametreleri; anket çalışması kapsamında doğal 1şık, yapay aydınlatma, gürültü kontrolü ve güvenlik sorularıyla birlikte değerlendirilmiştir (Şekil 3).

Değerlendirme sonucunda;

Yaş-doğal 1şık kontrolü ilişkisine bakıldı- ğında, UDH'de çalışan hemşirelerin yaş durumu ile doğal ışık kontrolü konusundaki memnuniyetleri arasında istatistiksel olarak anlamlılık görülmemekle birlikte; 21-25 yaş arası katılımcılardan \%50'sinin doğal 1şık kontrolünden memnun olmadığ1 görülmektedir. Diğer \%50 katılımcının ise "az memnun" ve "kararsız" olduğu görülmektedir. 26-30 yaş arası katılımcıların \%50'si “memnun", \%50'si ise "memnun değil"; 31-40 yaş arasındaki katılımcıların \%42,9'u “memnun”, \%35,7'si “memnun değil”" ve 41-50 yaş arası katılımcıların \%33,3'ü “memnun” ve \%33,3'ü “memnun değil”" şeklinde cevap vermiştir (Tablo 4).

ÇDH'de çalışan hemşirelerin yaş durumu ile doğal 1şık kontrolü konusundaki memnuniyetleri arasında istatistiksel olarak anlamlılık görülmemekle birlikte; 21-25 yaş aras1, \%33,3 “çok memnun”, \%33,3 "hiç memnun değill", \%33,3 "kararsız"; 26-30 yaş arası \%66,7 “memnun”, \%33,3 "çok memnun"; 31-40 yaş arası \%50 "çok memnun", \%16,7 “memnun”, \%16,7 "kararsız ve memnun değil"; 41-50 yaş arası \%25 "çok memnun", \%50 "memnun", \%25 "memnun değil”" şeklinde cevap vermiştir (Tablo 5).

Yaş-yapay aydınlatma kontrolü ilişkisi incelendiğinde, UDH'de çalışan hemşirelerin yaş durumu ile yapay 1 şık kontrolü konusundaki memnuniyetleri arasında istatistiksel olarak anlamlılık görülmemekle birlikte; 21-25 yaş arası katılımcılardan \%33,3'ünün yapay 1şık kontrolünden "hiç memnun olmadığı” görülmektedir. Diğer \%65 katılımcının ise "memnun" ve "çok

\begin{tabular}{|l|c|c|c|c|c|}
\hline & Kesinlikle katılmıorum & Katılmıyorum & Kararsızım & Katılıyorum & Kesinlikle katılıyorum \\
\hline $\mathrm{CDH}$ & 15,4 & 7,7 & 7,7 & 30,8 & 46,2 \\
\hline $\mathrm{UDH}$ & 23,3 & 26,7 & 13,3 & 36,7 & 0 \\
\hline
\end{tabular}

\begin{tabular}{|l|c|c|c|c|c|}
\hline & Kesinlikle katılmıorum & Katılmıyorum & Kararsızım & Katılıyorum & Kesinlikle katılıyorum \\
\hline $\mathrm{C} D H$ & 0 & 7,7 & 15,4 & 30,8 & 46,2 \\
\hline $\mathrm{UDH}$ & 0 & 33,3 & 20,0 & 46,7 & 0 \\
\hline
\end{tabular}

\begin{tabular}{|l|c|c|c|c|c|}
\hline & Kesinlikle katılmıorum & Katılmıyorum & Kararsızım & Katılıyorum & Kesinlikle katılıyorum \\
\hline $\mathrm{C}$ DH & 15,4 & 0 & 23,1 & 30,8 & 30,8 \\
\hline $\mathrm{UDH}$ & 6,7 & 20,0 & 6,7 & 46,7 & 20,0 \\
\hline
\end{tabular}




\begin{tabular}{|c|c|c|c|c|c|c|c|}
\hline & & & \multicolumn{5}{|c|}{ Doğal ışık kontrolü } \\
\hline & & & Hiç memnun değil & Memnun değil & Kararsiz & Memnun & Toplam \\
\hline \multirow[t]{16}{*}{ Yaş } & \multirow[t]{4}{*}{$21-25$} & say1 & 1 & 1 & 0 & 0 & 2 \\
\hline & & $\%$ yaş & $50,0 \%$ & $50,0 \%$ & $0,0 \%$ & $0,0 \%$ & $100,0 \%$ \\
\hline & & \% doğal ışık kontrolü & $14,3 \%$ & $12,5 \%$ & $0,0 \%$ & $0,0 \%$ & $6,7 \%$ \\
\hline & & $\%$ toplam & $3,3 \%$ & $3,3 \%$ & $0,0 \%$ & $0,0 \%$ & $6,7 \%$ \\
\hline & \multirow[t]{4}{*}{$26-30$} & say1 & 0 & 1 & 0 & 1 & 2 \\
\hline & & $\%$ yaş & $0,0 \%$ & $50,0 \%$ & $0,0 \%$ & $50,0 \%$ & $100,0 \%$ \\
\hline & & \% doğal ış1k kontrolü & $0,0 \%$ & $12,5 \%$ & $0,0 \%$ & $9,1 \%$ & $6,7 \%$ \\
\hline & & $\%$ toplam & $0,0 \%$ & $3,3 \%$ & $0,0 \%$ & $3,3 \%$ & $6,7 \%$ \\
\hline & \multirow[t]{4}{*}{$31-40$} & say1 & 2 & 5 & 1 & 6 & 14 \\
\hline & & $\%$ yaş & $14,3 \%$ & $35,7 \%$ & $7,1 \%$ & $42,9 \%$ & $100,0 \%$ \\
\hline & & \% doğal ışık kontrolü & $28,6 \%$ & $62,5 \%$ & $25,0 \%$ & $54,5 \%$ & $46,7 \%$ \\
\hline & & $\%$ toplam & $6,7 \%$ & $16,7 \%$ & $3,3 \%$ & $20,0 \%$ & $46,7 \%$ \\
\hline & \multirow[t]{4}{*}{$41-50$} & sayı & 4 & 1 & 3 & 4 & 12 \\
\hline & & $\%$ yaş & $33,3 \%$ & $8,3 \%$ & $25,0 \%$ & $33,3 \%$ & $100,0 \%$ \\
\hline & & \% doğal ış1k kontrolü & $57,1 \%$ & $12,5 \%$ & $75,0 \%$ & $36,4 \%$ & $40,0 \%$ \\
\hline & & $\%$ toplam & $13,3 \%$ & $3,3 \%$ & $10,0 \%$ & $13,3 \%$ & $40,0 \%$ \\
\hline \multirow[t]{4}{*}{ Toplam } & & sayı & 7 & 8 & 4 & 11 & 30 \\
\hline & & $\%$ yaş & $23,3 \%$ & $26,7 \%$ & $13,3 \%$ & $36,7 \%$ & $100,0 \%$ \\
\hline & & \% doğal ışı1k kontrolü & $100,0 \%$ & $100,0 \%$ & $100,0 \%$ & $100,0 \%$ & $100,0 \%$ \\
\hline & & $\%$ toplam & $23,3 \%$ & $26,7 \%$ & $13,3 \%$ & $36,7 \%$ & $100,0 \%$ \\
\hline
\end{tabular}

memnun" olduğu görülmektedir. 26-30 yaş arası katılımciların tamamı "memnun" ve "çok memnun"; 31-40 yaş arasındaki kat1lımcıların \%17'si “memnun değil”, \%17'si "karars1z", \%67'si "memnun" ve "çok memnun" ve 41-50 yaş arası katılımcıların $\% 25$ 'i "kararsiz" ve \%75'i "memnun" ve "çok memnun" şeklinde cevap vermiştir (Tablo 6).

ÇDH'de çalışan hemşirelerin yaş durumu ile yapay ışık kontrolü konusundaki memnuniyetleri arasında istatistiksel olarak anlaml1lık görülmemekle birlikte; 21-25 yaş arası, \%50 "memnun değil", \%50 "memnun"; 26-30 yaş arası \%50 "memnun", \%50 "kararsı"; 31-40 yaş aras1 \%21 "memnun değil", \%14 "kararsız", \%64 "memnun"; 41-50 yaş aras1 \%33 "memnun değil", \%25 "kararsız", \%33 "memnun" sonuçları elde edilmiştir. Hemşirelerin yaş durumu ile gürültü kontrolü konusundaki memnuniyetleri arasında istatistiksel olarak anlamlılık görülmemekle birlikte; yaş ortalamasının artmasıyla memnuniyet oranının her iki hastanede de azaldığ $\breve{l}_{1}$ belirlenmiştir. ÇDH'de çalışan hemşirelerin gürültü kont- rolünden memnuniyetleri, UDH'de çalışan hemşirelere göre daha yüksektir.

Çalışma süresi ve gürültü kontrolü konusundaki memnuniyet arasında istatistiksel olarak anlamlılık görülmemekle birlikte; 1 yıldan az çalışanlara göre, 1 yıldan fazladır hastanede çalışanların memnuniyetsizlik oranları daha yüksek olarak görülmektedir. Çalışma süresi ve doğal ışık kontrolü memnuniyeti arasında istatistiksel olarak anlamlılık görülmemekle birlikte; çalışma süresi arttıkça, doğal 1şık kontrolünden memnuniyetsiz olma durumunun arttığ izlenmektedir. Ayrıca, ÇDH'de çalışan hemşirelerin UDH'de çalışan hemşirelere göre doğal 1şık kontrolünden daha memnun oldukları görülmektedir. Çalışma süresi ve yapay aydınlatma kontrolü memnuniyeti arasında istatistiksel olarak anlamlılık görülmemekle birlikte; ÇDH'de çalışan hemşirelerin UDH'de çalışan hemşirelere göre yapay aydınlatma kontrolünden daha memnun oldukları görülmektedir. Ancak çalışma süresi ile yapay aydınlatma kontrolünden memnun olma durumu arasında herhangi bir ilişki gözlenmemiştir.
Tablo: 4

$U D H$ 'de çalışan hemşirelerin yas durumu ile çalısma alanlarındaki doğal ısıik kontrolü konusundaki memnuniyetleri arasindaki iliski. 


\begin{tabular}{|c|c|c|c|c|c|c|c|c|}
\hline & & & \multicolumn{6}{|c|}{ Doğal ıșık kontrolü } \\
\hline & & & Hiç memnun değil & Memnun değil & Kararsız & Memnun & Çok memnun & Toplam \\
\hline \multirow[t]{16}{*}{ Yaş } & \multirow[t]{4}{*}{$21-25$} & say1 & 1 & 0 & 1 & 0 & 1 & 3 \\
\hline & & $\%$ yaş & $33,3 \%$ & $0,0 \%$ & $33,3 \%$ & $0,0 \%$ & $33,3 \%$ & $100,0 \%$ \\
\hline & & \% doğal 1şık kontrolü & $100,0 \%$ & $0,0 \%$ & $50,0 \%$ & $0,0 \%$ & $16,7 \%$ & $18,8 \%$ \\
\hline & & $\%$ toplam & $6,3 \%$ & $0,0 \%$ & $6,3 \%$ & $0,0 \%$ & $6,3 \%$ & $18,8 \%$ \\
\hline & \multirow{4}{*}{$26-30$} & say1 & 0 & 0 & 0 & 2 & 1 & 3 \\
\hline & & $\%$ yaş & $0,0 \%$ & $0,0 \%$ & $0,0 \%$ & $66,7 \%$ & $33,3 \%$ & $100,0 \%$ \\
\hline & & \% doğal 1şık kontrolü & $0,0 \%$ & $0,0 \%$ & $0,0 \%$ & $40,0 \%$ & $16,7 \%$ & $18,8 \%$ \\
\hline & & $\%$ toplam & $0,0 \%$ & $0,0 \%$ & $0,0 \%$ & $12,5 \%$ & $6,3 \%$ & $18,8 \%$ \\
\hline & \multirow[t]{4}{*}{$31-40$} & say1 & 0 & 1 & 1 & 1 & 3 & 6 \\
\hline & & $\%$ yaş & $0,0 \%$ & $16,7 \%$ & $16,7 \%$ & $16,7 \%$ & $50,0 \%$ & $100,0 \%$ \\
\hline & & \% doğal 1şık kontrolü & $0,0 \%$ & $50,0 \%$ & $50,0 \%$ & $20,0 \%$ & $50,0 \%$ & $37,5 \%$ \\
\hline & & $\%$ toplam & $0,0 \%$ & $6,3 \%$ & $6,3 \%$ & $6,3 \%$ & $18,8 \%$ & $37,5 \%$ \\
\hline & \multirow[t]{4}{*}{$41-50$} & say1 & 0 & 1 & 0 & 2 & 1 & 4 \\
\hline & & $\%$ yaş & $0,0 \%$ & $25,0 \%$ & $0,0 \%$ & $50,0 \%$ & $25,0 \%$ & $100,0 \%$ \\
\hline & & \% doğal 1şık kontrolü & $0,0 \%$ & $50,0 \%$ & $0,0 \%$ & $40,0 \%$ & $16,7 \%$ & $25,0 \%$ \\
\hline & & $\%$ toplam & $0,0 \%$ & $6,3 \%$ & $0,0 \%$ & $12,5 \%$ & $6,3 \%$ & $25,0 \%$ \\
\hline \multirow[t]{4}{*}{ Toplam } & & say1 & & 2 & 2 & 5 & 6 & 16 \\
\hline & & $\%$ yaş & & $12,5 \%$ & $12,5 \%$ & $31,3 \%$ & $37,5 \%$ & $100,0 \%$ \\
\hline & & \% doğal 1şık kontrolü & & $100,0 \%$ & $100,0 \%$ & $100,0 \%$ & $100,0 \%$ & $100,0 \%$ \\
\hline & & $\%$ toplam & $6,3 \%$ & $12,5 \%$ & $12,5 \%$ & $31,3 \%$ & $37,5 \%$ & $100,0 \%$ \\
\hline
\end{tabular}

Tablo: 5

çDH'de çalışan hemşirelerin yaş durumu ile çalışma alanlarındaki doğal ışık kontrolü konusundaki memnuniyetleri arasındaki illişki.
ÇDH'de görme engeli olduğunu belirten herhangi bir hemşire yoktur. UDH'de ise görme engeli olan katılımcıların tamamı doğal 1ş1k kontrolünden memnun olmad1ğını ve yapay aydınlatma kontrolü konusunda kararsız olduklarını ifade etmektedir. ÇDH de ve UDH de engel durumu ile güvenlik arasında ilgili değişkenlerde anlamlılık kaydedilmemiştir.

\subsection{Mülakat Verileri}

Aidiyet konusu katılımcılar tarafindan değerlendirilirken çoğunlukla mobilya ile ilişki kurulmaktadır. Mobilyalar hemşirelerin mekâna duydukları aidiyette etkili bir rol oynamaktadır. Katılımcılar, mobilyalardaki renk, doku, yeterli sayıda olma gibi değişkenlerin aidiyet konusunda önemli birer kriter olduğunu vurgulamıştır.

ÇDH'deki katılımcılardan biri hemşire bankosunun kullanım amacina uygun olmadığını, daha çok bir sekreterya şeklinde düzenlendiğini ve kullanım alanı olarak yetersiz büyüklükte olduğunu belirtmiştir (Şekil 4, 6). Tedavi odası ve depolama odasının da oldukça küçük olduğu ve tedavi odasın- da lavabo olmadığı için zorluk çektiklerini belirtmiştir (Şekil 4). Evrak, malzeme ve donanım için ek alan ve bu alanda mobilya ihtiyacı olduğu anlaşılmaktadır. Tedavi odasında bulunması gereken bazı cihazların, yer olmadığı için depo ya da dinlenme odası gibi farklı alanlara taşınarak çözüm yaratıldığı belirtilmiştir. İlaçların depolandığı buzdolabı dinlenme odasında konumlandırılmıştır. Tedavi odasında bulunması gereken lavabo eksikliğinden dolayı hemşirelerin dinlenme odasındaki ya da tuvalet alanındaki lavabolardan birini kullanmak zorunda kaldığı aktarılmıştır. Tüm bu fiziksel ve donanımsal yetersizlikler nedeniye aidiyet duygusunun oldukça zedelendiği söylenebilir. Öte yandan ÇDH'de aynı katılımcı çalışma alanındaki aidiyet duygusunun çalışma alanında kendisi için çok fazla önemli olmadığını, daha çok dinlenme alanında bu konuyu önemsediğini söylemiştir. ÇDH'de katılımcılardan biri renk tercihi olarak özellikle cerrahi grup servislerinde daha dinlendirici tonlar olmasını istemiştir. Tedavi odasında ise daha uyarıcı olan canlı renklerin kendileri- 


\begin{tabular}{|c|c|c|c|c|c|c|c|c|}
\hline & & & \multicolumn{6}{|c|}{ Yapay aydınlatma kontrolü } \\
\hline \multirow[t]{11}{*}{ Yaş } & \multirow[t]{3}{*}{$21-25$} & sayı & 1 & 0 & 0 & 1 & 1 & 3 \\
\hline & & \% doğal 1ş1k kontrolü & $100,0 \%$ & $0,0 \%$ & $0,0 \%$ & $16,7 \%$ & $16,7 \%$ & $18,8 \%$ \\
\hline & & $\%$ toplam & $6,3 \%$ & $0,0 \%$ & $0,0 \%$ & $6,3 \%$ & $6,3 \%$ & $18,8 \%$ \\
\hline & \multirow{3}{*}{$26-30$} & $\%$ yaş & $0,0 \%$ & $0,0 \%$ & $0,0 \%$ & $66,7 \%$ & $33,3 \%$ & $100,0 \%$ \\
\hline & & $\%$ doğal 1şık kontrolü & $0,0 \%$ & $0,0 \%$ & $0,0 \%$ & $33,3 \%$ & $16,7 \%$ & $18,8 \%$ \\
\hline & & $\%$ toplam & $0,0 \%$ & $0,0 \%$ & $0,0 \%$ & $12,5 \%$ & $6,3 \%$ & $18,8 \%$ \\
\hline & \multirow[t]{2}{*}{$31-40$} & say1 & 0 & 1 & 1 & 1 & 3 & 6 \\
\hline & & $\%$ yaş & $0,0 \%$ & $16,7 \%$ & $16,7 \%$ & $16,7 \%$ & $50,0 \%$ & $100,0 \%$ \\
\hline & \multirow{3}{*}{$41-50$} & $\%$ yaş & $0,0 \%$ & $0,0 \%$ & $25,0 \%$ & $50,0 \%$ & $25,0 \%$ & $100,0 \%$ \\
\hline & & $\%$ doğal 1şık kontrolü & $0,0 \%$ & $0,0 \%$ & $50,0 \%$ & $33,3 \%$ & $16,7 \%$ & $25,0 \%$ \\
\hline & & $\%$ toplam & $0,0 \%$ & $0,0 \%$ & $6,3 \%$ & $12,5 \%$ & $6,3 \%$ & $25,0 \%$ \\
\hline \multirow[t]{4}{*}{ Toplam } & & say1 & & 1 & 2 & 6 & 6 & 16 \\
\hline & & $\%$ yaş & & $6,3 \%$ & $12,5 \%$ & $37,5 \%$ & $37,5 \%$ & $100,0 \%$ \\
\hline & & \% doğal 1şık kontrolü & & $100,0 \%$ & $100,0 \%$ & $100,0 \%$ & $100,0 \%$ & $100,0 \%$ \\
\hline & & $\%$ toplam & & $6,3 \%$ & $12,5 \%$ & $37,5 \%$ & $37,5 \%$ & $100,0 \%$ \\
\hline
\end{tabular}

\begin{tabular}{|c|c|c|c|c|c|c|}
\hline & & & \multicolumn{4}{|c|}{ Yapay aydınlatma kontrolü } \\
\hline & & & Memnun değil & Kararsız & Memnun & Toplam \\
\hline \multirow[t]{16}{*}{ Yaş } & \multirow[t]{4}{*}{$21-25$} & say1 & 1 & 0 & 1 & 2 \\
\hline & & $\%$ yaş & $50,0 \%$ & $0,0 \%$ & $50,0 \%$ & $100,0 \%$ \\
\hline & & \% doğal 1şık kontrolü & $10,0 \%$ & $0,0 \%$ & $7,1 \%$ & $6,7 \%$ \\
\hline & & $\%$ toplam & $3,3 \%$ & $0,0 \%$ & $3,3 \%$ & $6,7 \%$ \\
\hline & \multirow[t]{4}{*}{$26-30$} & say1 & 1 & 1 & 0 & 2 \\
\hline & & $\%$ yaş & $50,0 \%$ & $50,0 \%$ & $0,0 \%$ & $100,0 \%$ \\
\hline & & \% doğal 1şık kontrolü & $10,0 \%$ & $16,7 \%$ & $0,0 \%$ & $6,7 \%$ \\
\hline & & $\%$ toplam & $3,3 \%$ & $3,3 \%$ & $0,0 \%$ & $6,7 \%$ \\
\hline & \multirow[t]{4}{*}{$31-40$} & say1 & 3 & 2 & 9 & 14 \\
\hline & & $\%$ yaş & $21,4 \%$ & $14,3 \%$ & $64,3 \%$ & $100,0 \%$ \\
\hline & & \% doğal 1şık kontrolü & $30,0 \%$ & $33,3 \%$ & $64,3 \%$ & $46,7 \%$ \\
\hline & & $\%$ toplam & $10,0 \%$ & $6,7 \%$ & $30,0 \%$ & $46,7 \%$ \\
\hline & \multirow[t]{4}{*}{$41-50$} & say1 & 5 & 3 & 4 & 12 \\
\hline & & $\%$ yaş & $41,7 \%$ & $25,0 \%$ & $33,3 \%$ & $100,0 \%$ \\
\hline & & \% doğal 1şık kontrolü & $50,0 \%$ & $50,0 \%$ & $28,6 \%$ & $40,0 \%$ \\
\hline & & $\%$ toplam & $16,7 \%$ & $10,0 \%$ & $13,3 \%$ & $40,0 \%$ \\
\hline \multirow[t]{4}{*}{ Toplam } & & say1 & & 6 & 14 & 30 \\
\hline & & $\%$ yaş & & $20,0 \%$ & $46,7 \%$ & $100,0 \%$ \\
\hline & & \% doğal 1şık kontrolü & & $100,0 \%$ & $100,0 \%$ & $100,0 \%$ \\
\hline & & $\%$ toplam & & $20,0 \%$ & $46,7 \%$ & $100,0 \%$ \\
\hline
\end{tabular}

Tablo: 6

$U D H ' d e$ çalışan hemşirelerin yaş durumu ile çalısma alanlarındaki yapay aydınlatma kontrolü konusundaki memnuniyetleri arasındaki ilişki.

\section{Tablo: 7}

çDH'de Çalışan hemşirelerin yaş durumu ile çalışma alanlarındaki yapay aydınlatma kontrolü konusundaki memnuniyetleri arasındaki ilişki. 
Şekil: 6

Çeşme Devlet Hastanesi, hemşire bankosu.

\section{Şekil: 7}

Urla Devlet Hastanesi, hemşire bankosu ve arka bölümündeki depolama odası. ne canlılık kazandıracağını ve aidiyetlerini güçlendireceğini belirtmiştir.

UDH'deki katılımcılardan biri mobilyada öncelik sırası olarak görsellik, kullanılabilir olma ve kolay temizlenebilirliğ $i$ belirtmiştir. Çalışma alanındaki sandalye sayısının yeterli olmadığını ve mevcutların da ergonomik açıdan uygun olmadığını eklemiştir (Şekil 5, 7). Bir katılımcı çalışma alanında ek mobilya ihtiyacı için yazıcının durabileceği bir ünite sayesinde uzak mesafeye gitmek zorunda kalmayacakları için gün içindeki zaman kayıplarının azalacağını belirtmiştir. Ayrıca katılımcının, bu alanda kişisel eşyalarını (bardak, su şişesi, çanta, vb.) saklayabileceği kapaklı bir dolap isteği bulunmaktadır. Tüm bu ihtiyaçların de aidiyet duygusu ile doğrudan bağlantısı olduğu söylenebilir. Diğer katılımcı çalışma alanında açık renk kullanılmasının motive edici olduğunu ve mevcut durumdan memnuniyetini dile getirmiştir (Şekil 5, 7).

Sinır konusu, katılımcılar tarafindan olumlu veya olumsuz olarak değerlendirilebilmektedir. Sınır kavramının gerekliliğine inanan katılımcılar olduğu gibi, sınırı hasta ile aralarındaki bağı zayıflatıcı bir etken olarak değerlendiren katılımcılar da mevcuttur. Her iki hastanede de bu konuda mobilyalar ve sosyal ilişki neden olarak gösterilmiştir. ÇDH'de çalışma bankolarının yükseklikleri yetersiz olarak değerlendirilmiştir. Katılımcılardan biri hemşire bankolarının yüksekliğinin bel seviyesinin altında olduğunu ve bu nedenle hasta ve/ya hasta yakınıyla doğrudan muhatap kaldıklarını belirtmiştir (Şekil 6). Aynı katılımc1, hemşire çağrı sistemi doğru kullanıldığında ve herhangi bir tehdit unsuru olmadığ1 durumlarda bu tür birebir ilişki kurmaya çok gerek kalmayacağı için çalışma bankosunun mevcut yüksekliğinin verimli kullanılabileceğini eklemiştir. Sınırla ilgili olarak aynı katılımc hasta yakınları ile hemşire bankosunda hasta ya da yakını ile birebir ilişkiye girmeden de çağrı sistemi gibi birtakım çözümler üretilebileceğini, böylece bankonun standart çalışma masası yüksekliğinde yapılabileceğini belirtmiştir. $\mathrm{Bu}$ durumda karşılıklı ilişki kurmanın daha kolay olduğu, banko yüksekliğini arttırarak sınırı daha fazla korumanın bir bakıma da bu sosyal ilişkiyi zayıflattığını eklemiştir. UDH'de bankonun biçiminin bu konuda önemli olduğu ve L tipi çalışma bankolarının sınır oluşturma konusunda kendilerine destek olduğu belirtilmiştir (Şekil 5, 7). Bunun dışında hastalar ile sınır oluşturma konusunda mobilya düzeninden daha çok sosyal ilişkinin önemli olduğu vurgulanmıştır.
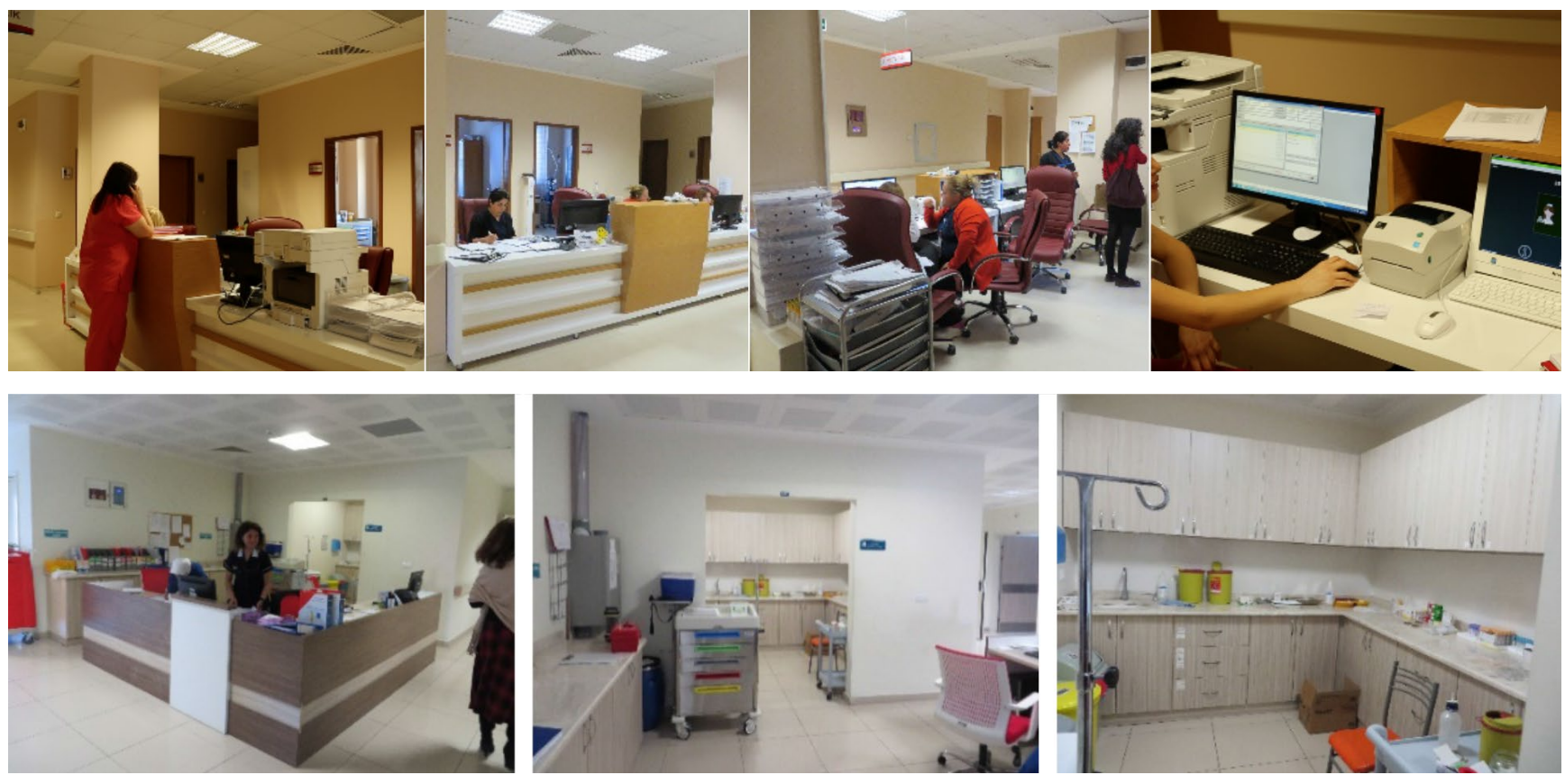
Güvenlik konusu katılımcilar tarafindan sağlık, mobilyaların ergonomisi ve zeminde kullanılan malzemelerin iș güvenliği açısından yeterliliği gibi farklı açılardan değerlendirilmiştir. ÇDH'de hasta ile ilgilenirken mobilyaların çekilmek zorunda olması, uzun vadede çalışanların fiziksel sağlığını bozan, aynı zamanda hastaya müdahaleyi önleyen bir durum olarak kat1lımcılar tarafindan belirtilmiştir. Mobilyaların ağırlığından şikayet edilmiştir. Zemin malzemesi konusunda UDH'de kayganlik sorun olarak belirtilmiştir. UDH'de katılımcılardan biri zemin malzemesinin parlak olmasını (kendisini motive etmesi açısından) tercih ettiğini belirtmiş ancak güvenlik açısından kaygan olmaması gerektiğini eklemiştir. UDH'deki diğer katılımcı da zemin malzemesinin kaygan olduğunu ve her temizlikte düşme tehlikesinden dolayı tedirginlik yaşadığını belirtmiştir. Ancak zemin malzemesinin enfeksiyon kaynağ olmamasının en önemli kriter olduğunu eklemiştir. UDH'deki iki katılımcı da mobilyaların fiziksel kullanıma uygun olmadığını, özellikle bilgisayar başındakilerin bel desteğine ihtiyaç duyduğunu belirtmiştir. Bilgisayar ekranlarının göz hizasının çok altında kalması nedeniyle bel ve boyun ağrıları yaşadıklarını (amnestek hastalı̆̆) ve buradaki sandalye, masa ve bilgisayarların konumlarının uygun olmadığını ayrıca ayaklar için de destek ihtiyacı olduğunu eklemiştir. Ayrıca katılımcılar tarafından çalışma sandalyelerinde sırt desteği yanı sıra kol desteği olması gerektiği de belirtilmiştir. Gürültü kontrolü konusu incelendiğinde her iki hastanede de gürültü kaynağının temel nedeninin hasta yoğunluğundan ortaya çıkan sesler olduğu anlaşılmaktadır. Ayrıca diğer gürültü kaynakları arasında tıbbi cihazlar ve personelin kendi aralarındaki konuşmaları yer almaktadır.

ÇDH'de gürültü kontrolünün hasta kaynaklı gürültüden, katlar ve mekânlar arası yalıtım azlığından dolayı sorun olduğu belirtilmiştir. Bunun dışında cihazların çekilme sesleri, hastalara bağlanan kalp ritm cihaz sesleri ve personelin birbirine seslenmesi gürültü kaynakları olarak bildirilmiştir. Aynı zamanda, çalışma mekânında personelin kendi arasında yaptığ 1 konuşmaların hasta odalarından duyulduğu ve bunun büyük bir problem olduğu da katılımcılar tarafindan not düşülmüştür. Bunun personelin konforunu etkileyerek stres seviyelerini arttırdığını belirtmiştir. Aynı zamanda hastalar için de rahatsızlık yarattığını ve hastanın sağlık durumu üzerine olan konuşmaların mahremiyet açısından hastayı olumsuz etkilediğini belirtilmiştir. ÇDH'deki katılımcılardan biri hastadan ve personelden kaynaklanan gürültülerin önlenmesi için ses yalıtımı ile ilgili önlemlerin alınması gerektiğini vurgulayarak odalar arası, katlar arası ve genel kullanım alanlarında döşeme, mobilya ve duvarlarda seçilen malzemelerin ses emici özellikte olması önerisini sunmuştur. Bunun yanı sıra, hastanenin kurulduğu ilk yıllarda jeneratör sesinin rahatsızlık verdiği, ancak sonraki dönemde bunu engellemek üzere bir ses perdesi yapıldı $\breve{g}_{1}$ belirtilmiştir. UDH'de gürültü kontrolü konusunda en büyük sorun hasta yoğunluğu olduğu belirtilmiştir. Hasta sirkülasyonu, yatış ve taburcu işlemleri, bu gürültünün ana nedenleri olarak gösterilmiştir. Bunun yanı sıra, sedye ve yemekhane arabasının sesi diğer bir gürültü kaynağı olarak görülmektedir. Kardiyoloji biriminde çalışan bir katılımcı, hastaya bağlanan monitör seslerinin büyük bir gürültü kaynağı olduğunu, pump seslerinin sürekli ses yaptığını belirtmektedir. Bu seslere hastaların gürültüsü de eklenince personelin mesai bitiminde gürültüden kaynaklı aşırı bir yorgunluk hissettiğini eklemiştir. Gürültü, katılımcılar için çok büyük bir problem olarak gösterilmektedir. Gürültüye çözüm önerisi olarak yalıtım, doğru malzeme seçimi ve bireylerin eğitimi üzerinde durulmuştur.

Koku kontrolü konusunda her iki hastanede hemşirelerin en fazla şikayetçi olduğu koku kaynağ 1 yemekhane olarak belirtilmiştir. Temizlik malzemelerinden gelen ve hasta kaynaklı kokular da rahatsız edici diğer koku kaynakları olarak sıralanmaktadır. ÇDH'de katılımcılar yemekhane kokularının çalışma alanlarına gelmesinden olan memnuniyetsizliklerini dile getirmektedir. Bunun yanı sıra az da olsa temizlik malzemelerinden kaynaklanan kokular da onlar 
için bir rahatsızlık sebebi olarak görülmektedir. Ayrıca, ilaç kokusu, laboratuvar kokusu, medikal gaz kokusundan rahatsız olan meslektaşları olduğunu belirten katılımcılar, ÇDH'de bu durumun olmadığını, bunu sağlayan en önemli etkenin ise bu mekânların iyi izole edilmesi, konum olarak en alt katta ve havalandırmalarının ayrı çözülmüş olduğunu söylemişlerdir. Ancak, hasta kaynaklı kokunun onlar için bir sorun olduğu not edilmiştir. UDH'de katılımcılar en büyük koku kaynağının yemekhane olduğunu ve bu kokunun tüm hastaneye yayıldığını belirtmişlerdir. Bunun yanı sıra hastanın bireysel hijyeninin yeterli olmad1ğını ve bunun kendilerini rahatsız ettiğini dile getirmişlerdir. Ayrıca, el dezenfektanları dışında kalan yüzey temizliği için kullanılan dezenfektanların kokularının rahatsız edici olduğu belirtilmiştir.

Mahremiyet konusunda her iki hastanede de hemşirelerin mahremiyeti konusunda üzerinde durulan konular arasında, ses yalıtımının yetersizliği nedeniyle personel çalışma mekânlarında konuşulanların hasta odalarından duyulması mahremiyeti zedeleyen en önemli eksiklik olarak ortaya çıkmaktadır. ÇDH'de, çalışma mekânlarından hasta odalarına ulaşan ses nedeniyle konuşmaların hastalar tarafından duyuluyor olması, katılımcilar tarafindan mahremiyetlerini zedeleyici bir durum olarak değerlendirilmektedir. Çalışanların mahremiyetinin dinlenme ve giyinme odalarında sağlanması, hemşire çalışma bankosunda her zaman bir görevli olması nedeniyle bu mekânlara hasta/hasta yakınlarının erişiminin kontrol edilebilmesi ve kendilerine ait ayrı bir tuvaletleri olması, mahremiyet açısından olumlu yönler olarak değerlendirilmiştir. UDH'de katılımcılar tarafindan mahremiyet konusunda hastane içinde sürekli eğitimler verildiği belirtilmiştir. Bu eğitimlerin hem hasta hem de sağlık çalışanlarını kapsadığı söylenmiştir. Ancak, hastaların mahremiyetine gösterilen özenin kendilerine gösterilmemesi, katılımcılar için sorun olarak değerlendirilmiştir. Hemşirelerin çalışma alanlarına izin istenmeden giriş yapılması kendilerini rahatsız etmektedir.

\section{Tartışma ve Sonuçlar}

Hemşire çalışma alanlarındaki mekânsal memnuniyeti psikososyal beklentiler üzerinden değerlendirmek amacıyla yapılan bu çalışmada; katılımcılardan ÇDH'de çalışan hemşirelerin, UDH'de çalışan hemşirelere göre daha uzun süredir belirtilen hastanede çalıştıkları görülmüştür. UDH'de çalışan hemşirelerin ise yaş ortalamasının ÇDH'de çalışan hemşirelere oranla daha yüksek olduğu gözlenmiştir. Psikososyal gereksinimleri karşılamaya yönelik mekânsal verilerin yeterliliği incelendiğinde;

ÇDH'de doğal ışık kontrolünün katılımcılar tarafindan daha iyi olarak değerlendirildiği, benzer şekilde yapay aydınlatma kontrolünde de ÇDH'nin UDH'ne göre kullanıcıları daha çok memnun ettiği görülmektedir. Doğal 1ş1k kontrolünden memnuniyette katılımcıların çalışma sürelerinin etkili olduğu anket verilerinde gözlemlenmiştir.

Gürültü kontrolü konusunda her iki hastanedeki memnuniyet oranları birbirine yakın olmakla birlikte, UDH hemşirelerinin çalışma alanlarındaki gürültü kontrolünden daha memnun oldukları anlaşılmaktadır. Gürültü kaynağı olarak her iki hastane katılımcilarının hasta ve yakınlarından kaynaklanan gürültüden ve cihaz seslerinden rahatsız oldukları görülmektedir.

Koku kontrolünde yaşanan sorunlarda en önemli kaynak, her iki hastanede de yemekhaneler olarak kaydedilmektedir. Bunun yanı sıra, hastaların kişisel hijyenlerine yeterli özeni göstermemelerinden kaynaklanan koku da hemşireler için bir sorun oluşturmaktadır. Her iki hastane kat1lımcılarının az da olsa yüzey temizliği için kullanılan malzemelerden rahatsız olduğu görülmektedir.

Güvenlik konusunda, her iki hastanede de kablolar yüksek risk olarak görülmektedir. Mobilyalar; konum, büyüklük, boyut, ergonomik şartlara uyum (bilgisayar yüksekliğinin göz hizasina uygun olma durumu, sandalye-bel uyumu, çalışma bankosu yüksekliği, vb.) bakımından her iki hastane katılımcıları tarafından yüksek risk olarak değerlendirilmektedir. ÇDH'de zemin malzemesi kullanıcılar tarafından daha büyük risk olarak görülür- 
ken, UDH'de bu durum çok riskli görülmemekte, zemin malzemesinden memnun oldukları görülmektedir. ÇDH'de tıbbi malzemeler, prizler daha riskli görülürken; her iki hastanede de mekân boyutlarının uygun olmayıșı güvenlik konusunda bir risk olarak değerlendirilmektedir. Böylece, hava kalitesi, 1şık ve ses kalitesi konusundaki ergonomik uygulamaların sağlık çalışanlarının sağlığı üzerinde önemli ölçüde etkiye sahip olduğu sonucuna varmak mümkün olmaktadır (Ulrich vd., 2004).

Aidiyet konusunda katılımcılar, derinlemesine görüşmelerde daha çok dinlenme alanlarını vurgulamış; çalışma alanlarında aidiyet gereksinimlerinin daha düşük olduğunu belirtmiştir. Çalışma alanlarındaki aidiyette kullandıkları mobilyaların özellikle bitiş elemanlarının kendileriyle olan etkileşimi, mekâna aidiyetleri konusunda etkili olmaktadır.

Sınır konusunda da mekâna aidiyete benzer şekilde, mobilyaların etkisini vurgulamak gerekmektedir. Kişilerin çalışma alanlarında özellikle hasta ve yakınlarıyla aralarında gereksinim duydukları sınır için mobilyalar önemli birer iç mekân elemanıdır. Hemşire çalışma bankolarının yükseklik ve biçiminin doğru ele alınması gerekmektedir. Bir diğer vurgulanması gereken nokta ise sosyal ilişkilerdir. Her ne kadar mimari bir öğe olarak tasarıma katılmasa da mimarinin bu sosyal ilişkiyi tanımlama şekli, bu konudaki tedirginliği azaltacaktır.

Her iki hastane katılımcıları tarafindan mahremiyet konusuna alınan cevaplar ve literatür değerlendirildiğinde, mahremiyetin daha çok hasta odaklı ele alındığı ancak hemşireler için de bu konunun oldukça önem arz ettiği anlaşılmaktadır. Özellikle hasta ile olan ilişkilerinde mahremiyetlerini sağlamak konusunda sorun yaşadıkları görülmekte, ses izolasyonunun ve sosyal ilişkilerin buradaki en önemli belirleyiciler olduğu anlaşılmaktadır.

Çalışma tarafından belirlenen parametrelerden memnuniyetin; hemşirelerin öncelikle insan hakları ve çalışan haklarının korunması, sonrasında hastaya karşı olan hoşgörü ve iyi iş gücü anlamında iş performanslarının artması, strese, güvenlik

64 Sayı 34, Kasım 2021 ihlaline ve yorgunluğa bağlı iş kazalarının azalması ve dolayısıyla sağlık hizmetlerinin veriminin artması için kaçınılmaz olduğu düşünülmektedir. Buna karşın, bu parametrelerdeki eksiklik ya da hataların tüm bu çıktıların negatif olmasında etkili olacağı anlaşılmaktadır. Çalışmada katılımcı olan hemşirelerin özellikle mülakat çalışmalarında oldukça istekli oldukları gözlenmiştir. Bu durum, sağlık çalışmaları ile ilgili gelecekte yapılacak çalışmalarda sağlık çalışanlarının görüşlerinin dikkate alınması gerekliliğini bir kez daha göstermektedir.

Son yıllarda sağlık birimlerine dair yönetmelik ve yönergeler giderek detaylandırılmakta ve mevzuatlar genişletilmekte olup, sağlık yapıları iç mekânlarında çalışan sağlık çalışanlarının özellikle psikososyal gereksinimlerini kapsayan herhangi bir resmi kabul ve standarta rastlanmamaktadır. $\mathrm{Bu}$ durum, sağlık çalışanlarının beklentilerinin somut bir şekilde biraraya getirilememesi ve optimum koşulların yönetmeliklerde yer alamaması olarak görülmektedir. Oysa sağlık sektöründe bütüncül bir başarı elde etmek için tüm alanları kapsayan ve farklı grupların rol aldığı bir yaklaşım sağlamak gerekmektedir. Hemşire çalışma alanlarındaki iç mekân koşullarının iyileştirilmesi konusunda yapılan bu araştırmanın da sağlık personelinin büyük bir bölümünü oluşturan hemşirelerin stres ve yorgunlugunu azaltarak iş performanslarını artırmak konusundaki çalışmalara katkı sağlayacağı düşünülmektedir• 


\section{Kaynakça}

Aiken, L. H., Sloane, D. M., Clarke, S., Poghosyan, L., Cho, E., You, L., Finlayson, M., Kanai-Pak, M. ve Aungsuroch, Y. (2011). Importance of work environments on hospital outcomes in nine countries. International Journal for Quality in Health Care: Journal of the International Society for Quality in Health Care, 23(4), 357-364. https:// doi.org/10.1093/intqhe/mzr022.

Applebaum, D.H. (2008). The relationship between physical work environmental factors, perceived stress, job satisfaction and turnover intention among inpatient acute care nurses. https://rucore. libraries.rutgers.edu/rutgers-lib/25757/. (Doktora Tezi). Rutgers University, New Brunswick, NJ, United States.

Bayızıtlığlu, B. (2009). Insan-mekân etkileşimi. (1. bs.). İstanbul: Edumar Eğitim Market.

Bayo, M.V., García, A.M. ve García, A. (1995). Noise levels in an urban hospital and workers' subjective responses. Archives of Environmental Health, 50(3), 247-251.

Berberoğlu, Ö. (2010). Algl, sınır, kişisel alan kavramları ve hastane tasarımı. (Yüksek Lisans Tezi). İstanbul Teknik Üniversitesi, İstanbul. https://polen.itu. edu.tr/handle/11527/3375.

Blomkvist, V., Eriksen, C. A., Theorell, T., Ulrich, R. ve Rasmanis, G. (2005). Acoustics and psychosocial environment in intensive coronary care. Occupational and Environmental Medicine, 62(3):e1. doi: 10.1136/oem.2004.017632

Cummings, G. G., MacGregor, T., Davey, M., Lee, H., Wong, C. A., Lo, E., Muise, M. ve Stafford, E. (2010). Leadership styles and outcome patterns for the nursing workforce and work environment: A systematic review. International Journal of Nursing Studies, 47, 363-385. https://doi. org/10.1016/j.ijnurstu.2009.08.006

Dalke, H., Little, J., Niemann, E., Camgoz, N., Steadman, G., Hill, S. vd. (2006). Colour and lighting in hospital design. Optics \& Laser Technology, 38 , 343-365.

De Nobile, J. (2003). Organisational communication, job satisfaction and occupational stress in catholic primary schools. http://unsworks. unsw.edu.au/fapi/datastream/unsworks:47915/ SOURCE01?view=true (Doktora Tezi). University of New South Wales, Sydney, Australia.

Donald, I. (1994). Management and change in office environments. Journal of Environmental Psychology, 14(1), 21-30. doi: https://doi.org/10.1016/ S0272-4944(05)80195-1.

Ebright, P.R., Patterson, E.S., Chalko, B.A. ve Render, M.L. (2003). Understanding the complexity of registered nurse work in acute care settings. The Journal of Nursing Administration, 33(12), 630-638. https://doi.org/10.1097/00005110-200312000-00004.

Evans, G.W. ve Cohen, S. (1987). Environmental stress. D. Stokols ve I. Altman (Der.), Handbook of Environmental Psychology içinde (Cilt 1, ss. 571-610). NY: Wiley.

Evans, G.W. ve McCoy, J.M. (1998). When buildings don’t work: the role of architecture in human health. Journal of Environmental Psychology, 18(1), 8594. doi: https://doi.org/10.1006/jevp.1998.0089.

Gatchel, R.J., Baum, A., Krantz, D.S. ve Singer, J.E. (1989). An introduction to health psychology. NY: Random House.
H. Dalke, J. Little, E. Niemann, N. Camgoz, G. Steadman, S. Hill, vd. (2006). Colour and lighting in hospital design. Optics \& Laser Technology, 38, 343-365.

Haddad, L.M., Annamaraju, P. ve Toney-Butler, T.J. (2020). Nursing shortage. Erişim adresi: https://www. ncbi.nlm.nih.gov/books/NBK493175/ [Erişim tarihi: 11 Ocak 2021]

Hayes, L.J., O'Brien-Pallas, L., Duffield, C., Shamian, J., Buchan, J., Hughes, F., vd. (2006). Nurse turnover: a literature review. International Journal of Nursing Studies, 43, pp. 237-263.

Jones, C.B. (2005). Nurse turnover: Why it is such a tough problem to solve? Nurse Leader, 3, 43-47.

Levin, B. M. ve Groner, N. E. (1992). Human Behavior Aspects of Staging Areas for Fire Safety in Gsa Buildings. National Institute of Standards and Technology, Building and Fire Research Laboratory, NIST-GCR-92-606.

Locke, E. A. (1976). The nature and causes of job satisfaction. M. D. Dunnette (Der.), Handbook of Industrial and Organizational Psychology içinde (Cilt 1, ss. 1297-1349). Chicago, IL: Rand McNally.

Malloch, K. ve O'Grady, T.P. (2006). Managing for success in health care. ABD: Mosby, Elsevier-Health Sciences Division.

Miner, J.B. (1992). Industrial-organizational psychology. Singapore: McGraw-Hill Int.

Mourshed, M. ve Zhao, Y. (2012). Healthcare providers' perception of design factors related to physical environments in hospitals. Journal of Environmental Psychology, 32(4), 362-370. https://doi.org/10.1016/J.JENVP.2012.06.004.

Nejati, A., Shepley, M., Rodiek, S., Lee, C. ve Varni, J. (2016). Restorative design features for hospital staff break areas: a multi-method study. Health Environments Research and Design Journal, 9(2), 16-35. doi: 10.1177/1937586715592632.

Norbeck, J. S. (1985). Perceived job stress, job satisfaction, and psychological symptoms in critical care nursing. Research in Nursing \& Health, 8(3), 253 259. doi: https://doi.org/10.1002/nur.4770080307.

O'Neill, M. ve Evans, G. (2000). Effects of workstation adjustability and training on stress and motivational performance. A. E. Stamps (Der.), 31st Conference of the Environmental Design Research Association içinde, (ss. 60-66). I. Edmond, OK: EDRA.

Potter, P., Faan, R.N., Wolf, L., Boxerman, S. Grayson, D., Sledge, J., Dunagan, C. ve Evanoff, B. (2005). Understanding the cognitive work of nursing in the acute care environment. JONA: The Journal of Nursing Administration, 35 (7), 327-335

Reason, J. (1997). Managing the risks of organizational accidents. Aldershot, England: Ashgate.

Relph, E. (1976). Place and placelessness. (Vol. 67). London: Pion.

Robert Wood Johnson Foundation \& Institute for Healthcare Improvement. (2006). A new era in nursing: Transforming care at the bedside. Erișim adresi: http://www.rwjf.org/files/publications/ other/TCABBrochure041007.pdf [Erișim tarihi: 29 Mayıs 2021]

Saegert, S. (2004). Book review: handbook of environmental psychology. Journal of Environmental Psychology, 24(2), 259-263.

Salama, A.M. ve Courtney, L. (2013). The impact of the spatial qualities of the workplace on architectś job 
satisfaction. Archnet-IJAR, 7(1), 52-64.

Tanriöver, S. (2016). The healing \& supportive role of design in healthcare environments: evidence based healthcare design. INAR 371 İç Mekânda Alg1 dersinde yapilan Healing Role of Space on the Design of Healthcare Buildings adlı sunum. İzmir: Yaşar Üniversitesi.

Tavakkoli, R. (2014). İç mimaride grafik tasarım. (Yüksek Lisans Tezi). Hacettepe Üniversitesi Güzel Sanatlar Enstitüsü, Ankara. https://docplayer.biz. tr/27440563-Hacettepe-universitesi-guzel-sanatlar-enstitusu-ic-mimarlik-ve-cevre-tasarimi-anasanat-dali-ic-mimaride-grafik-tasarim.html.

The American Association of Colleges of Nursing. (t.y.). Impact of the Nursing Shortage on Patient Care. Erişim adresi: https://www.aacnnursing.org/ News-Information/Nursing-Shortage-Resources/ Impact [Erişim tarihi 11 Ocak 2021]

Topf, M. ve Dillon, E. (1988). Noise-induced stress as a predictor of burnout in critical care nurses. Heart Lung: Journal of Critical Care, 17(5), 567-574.

Tuan, Y.F. (1977). Space and place: the perspective of experience. Minneapolis: University of Minnesota Press.

Ulrich, R., Quan, X., Anjali, J., Choudhary, R. ve Zimring, C. (2004). The role of the physical environment in the hospital of the 21st century: a once-in-a-lifetime opportunity. Erişim adresi: https://www. healthdesign.org/system/files/Ulrich_Role \%20 of\%20Physical_2004.pdf [Erişim tarihi: 20.10.2021]

Ulrich, R.S. (1999). Effects of gardens on health outcomes theory and research. C.Cooper ve M. ve M.Barnes (Der.) Healing Gardens: Therapeutic Benefits and Design Recommendations içinde (ss.27-86). New York: John Wiley \& Sons.

Ulrich, R.S. (2021). Evidence based environmental design for improving medical outcomes. Erişim adresi: https://www.brikbase.org/sites/default/files/ Evidence\%20Based\%20Environmental\%20 Design\%20for\%20Improving\%20Medical.pdf [Erişim tarihi: 12.04.2021]

Wells, M.M. (2000). Office clutter or meaningful personal displays: the role of office personalization in employee and organizational well-being. Journal of Environmental Psychology, 20(3), 239-255.

Wu, A. W. (2000). Medical error: the second victim. British Medical Journal, 320, 726-727. doi: 10.1136/ bmj.320.7237.726.

Zadeh, R. S., Shepley, M. M., ve Waggener, L. T. (2012). Rethinking efficiency in acute care nursing units: analyzing nursing unit layout for improved spatial workflow. Health Environments Research and Design Journal, 6, 39-65. 